\title{
Physicochemical and Microbiological Characterization of Karamunting (Rhodomyrtus tomentosa) Syrup
}

\author{
Widia Dara ${ }^{1}$, Dewi Yudiana Shinta ${ }^{2}$, Nurhamidah $^{3}$, Isma Wenny ${ }^{4}$ \\ \{widiadara@stikesperintis.ac.id\} \\ STIKES Perintis, Padang, Indonesia
}

\begin{abstract}
Karamunting (Rhodomyrtus tomentosa) plants are wild plants that have many benefits. This study aimed to determine organoleptic quality by the panelists' acceptance of the aroma, color, viscosity, and taste of syrup and to find the characteristics of microbiological quality. This research uses UV Vis spectrophotometer and total plate count method. Organoleptic test results of Rhodomyrtus tomentosa syrup ranged from likes to very liked by panelists. The results of analysis of vitamin $\mathrm{C}$ syrup content of $0.05 \%$ and sugar content of $17.90 \%$. Total acid of syrup is $0,26 \%$, and acidity value is 5,2 . No pathogenic bacteria E. coli, Staphylococcus aureus, and Salmonella were found. The total plate number was found as much as $2.5 \times 10^{2}$ colonies $/ \mathrm{ml}$. There were fungi as much as $1.0 \times 10^{2}$ colonies $/ \mathrm{ml}$. The analysis resulted that syrup still fulfilled the quality standard of microbiological set by the Indonesian National Standard. The results of this study indicate that syrup is safe to drink.
\end{abstract}

Keywords: High Fructose Corn Syrup, Microbiology, Organoleptic, Tomentosone B.

\section{Introduction}

Karamunting (Rhodomyrtus tomentosa) grows in the plains of West Sumatra, with different local names. In the city of Padang, it is called Tamboyo, in Tanah Datar called cik manih, in Limapuluh Kota it is known as domang, while in the Agam, Bukitinggi and Solok areas it is known by the name karamuntiang. According to Fahmi et al. [1]. Rhodomyrtus tomentosa has traditionally been used as a worm medicine, medicine for wounds, scabies, headaches, abdominal pain, and diarrhea, holding bleeding and preventing infection after giving birth. Rhodomyrtus tomentosa fruit is also used as an antidote and diarrhea medication.

Rhodomyrtus tomentosa is a wild plant and grows in places that get enough sunlight such as on mountain slopes and fields that are not too arid. The characteristics of this plant include a group of shrubs, single leaves, the base of rounded leaves, flat leaf edges, tapered leaf tips. Flowers include reddish-reddish compound flowers. The fruit is green after cooking into purpleblack [2].

Inside $100 \mathrm{~g}$ of Rhodomyrtus tomentosa fruit, there were $0.07 \%$ fat content, $0.12 \%$ protein, $2 \%$ ash content. Rhodomyrtus tomentosa fruit contains Fe minerals of $4.2 \mathrm{mg}$ and Vitamin C levels in weight of 150 which is $5.62 \mathrm{mg}$ and Vitamin E of $3.89 \mathrm{mg}$ [3]. Fe levels in mature Rhodomyrtus tomentosa fruits are more than young ones. In old and ripe fruit, there is Fe content of $19.1 \mathrm{mg} / 100 \mathrm{~g}$ of fruit. [4]

Syrup can be made from the basic ingredients of fruit, leaves, root seeds and other parts of plants. According to Uzlifah 2014 [5] syrup contains at least 50\% sucrose and is usually 60- 
$65 \%$. Meanwhile, according to Syamsuni [6] syrup is an oral solution containing high levels of sucrose or other sugars. According to SNI (2013)[7], the syrup is defined as a beverage product made from a mixture of water and sugar with a minimum sugar content of $65 \%$ with or without other food and/or food additives that are permitted by applicable regulations.

On the market there are various types of drinks, but those that function as health drinks are very few. Based on its function circulating drinks are grouped into 3 (three), namely thirst release drinks, drink drinks and health drinks [8].

The Rhodomyrtus tomentosa syrup made in this study is included in a refreshing and healthy drink because the content of the substance contained in the Rhodomyrtus tomentosa fruit. Besides making syrup makes it easier for consumers to consume it and, it can be stored in the long term. This study aimed to analyze the effect of processing Rhodomyrtus tomentosa fruit on syrup on physicochemical and microbiology.

\section{Materials and Methods}

The raw materials used in this study are Rhodomyrtus tomentosa fruit, sugar, and water. Rhodomyrtus tomentosa is obtained from the Lumpo of Pesisir Selatan district, West Sumatera, Indonesia. The fruit that is used is that has a ripe blackish purple color. The material used for chemical analysis is vitamin C L (+) Ascorbic acid (Merck), ethanol, PCA, PDA, and SA (merck) media. The tools used in this study were T70UV / Vis spectrophotometry (PGI), counter colony and autoclave, $\mathrm{pH}$ meter and tools of titration.

The first stage is the organoleptic test. The research design was carried out with 3 treatments. The data obtained were analyzed using the Analysis of Variance and Duncan's variance and distance test analysis (DNMRT) of 5\%. The sensory analysis includes color, aroma, viscosity, and taste.

The most preferred organoleptic test results are followed by the analysis of physics and microbiological. Observations made on Rhodomyrtus tomentosa syrup are $\mathrm{pH}$, vitamin $\mathrm{C}$, total acid, sugar content, microbial contamination test, and total plate number. The standard procedure for the quality of the chemical $\mathrm{pH}(\mathrm{pH}$ meter) and the amount of acid are AOAC (1995), the procedure for measuring vitamin C levels is read by UV Vis spectrophotometry. Measuring results are using a calibration curve. A standard curve, where there is a concentration relationship with absorbance value. Then the value that can be known is the value of the Slope and intercept. Then the sample concentration value can be known by entering into the regression equation by using Lambert-Beer law.

\section{Results and Discussion}

\subsection{Organoleptic Test}

The organoleptic test is a way to find out the panelist's acceptance of a beverage product. In general, a person's main consideration in buying or consuming food or drinks is their quality or organoleptic characteristics such as color, aroma, viscosity, and taste. Only certain people buy or consume food or drinks with the main consideration of chemical quality (nutritional value) [9]. In this study, a hedonic scale test was carried out, namely testing the preference for color, aroma, viscosity, and taste of syrup. There was 30 panelists tested this syrup. A level assessment 
of product made using a hedonic scale of 1 to 5 , meaning that $1=$ extremely dislike, $2=$ dislike, $3=$ somewhat, $4=$ likes and $5=$ very like. Here is the result of observations made in the sensory analysis ( Figure 1).

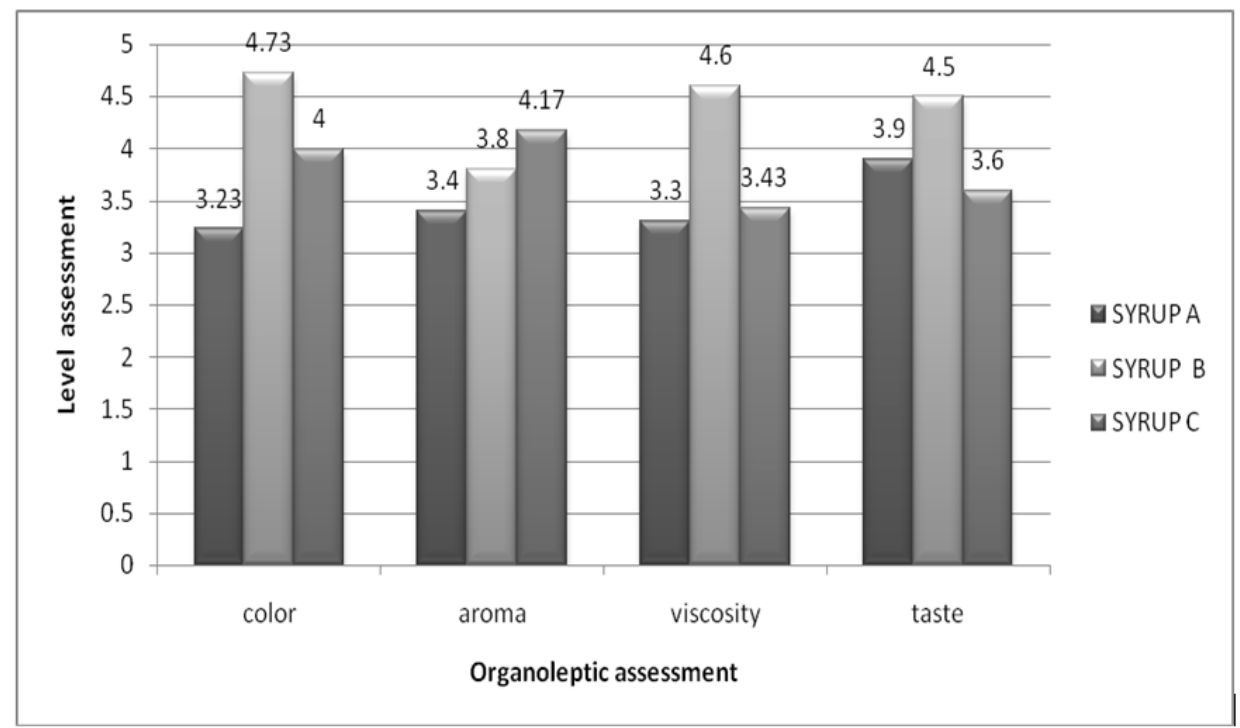

Fig. 1. Value of Organoleptic Test for Rhodomyrtus tomentosa Syrup

\subsection{Color Quality}

Color is an appearance that can be seen directly by the sense of sight. The color factor is an initial parameter that must be subjectively and visually considered because it can cause rejection or acceptance of a product. The average value of preference for the color of Rhodomyrtus tomentosa fruit syrup given by panelists ranged from 3.23 to 4.73 . The color most preferred by panelists is syrup made with treatment $B$ which is a fruit that is cut into pieces before being cooked where the color is dark purple syrup and the syrup with treatment $\mathrm{A}$ and $\mathrm{C}$ is less dense.

Based on the ANOVA test, the calculated F value (6.75) was then compared with the F table with a value (2.92) at the $5 \%$ real level. F count is greater than $\mathrm{F}$ table so it can be stated that there are significant differences between treatments. The results of the test were continued with the Duncan Multiple Range Test (DMRT) at the 5\% level of test. It is found that treatment A was significantly different from treatment B, and treatment A had no significant difference with treatment $\mathrm{C}$ and $\mathrm{C}$ there was no significant difference with treatment $\mathrm{B}$. The color preferred by panelists is treatment $\mathrm{B}$ with a value of 4.73 means very like.

\subsection{Aroma Quality}

The taste of food ingredients consists of components, namely aroma, and oral stimulation. The smell determines the delicacy of a food ingredient be accepted or rejected by the panelist. The average value of preference for the color of the Rhodomyrtus tomentosa fruit syrup given by the panelists ranged from 3.40 to 4.17 . The aroma most preferred by panelists is syrup with one made with treatment $\mathrm{C}$ which is the fruit that is heated first freshly cooked where the color of 
purple syrup is not too thick. Based on the ANOVA test, it was found that F calculated (1.79) was then compared with the F table with a value (2.92) at the 5\% real level. F count is smaller than $\mathrm{F}$ table so it can be concluded that there is no significant difference in aroma. The aroma preferred by panelist treatment C 4.17 means likes.

\subsection{Viscosity Quality}

Viscosity is an outward appearance of a product that can be seen directly. Viscosity in beverage products will affect the assessment of whether or not the product is received. The average value of preference for the viscosity of Rhodomyrtus tomentosa fruit syrup given by panelists ranged from 3.30 to 4.60 . The most preferred panelist viscosity is syrup made with treatment B. Syrup is made by cutting the fruit first, then cooked. Based on the ANOVA test, the calculated F value (9.96) was then compared with the $\mathrm{F}$ table of value (2.92) at the 5\% real level. F count is greater than $\mathrm{F}$ table so it can be stated that there are significant differences between treatments. The test results are continued with the Duncan Multiple Range Test (DMRT) test at level 5\% found treatment $\mathrm{A}$ had a significant difference with treatment $\mathrm{B}$, and treatment $\mathrm{A}$ had no significant difference with treatment $\mathrm{C}$ and $\mathrm{C}$ there were significant differences with treatment $\mathrm{B}$. The taste of the panelists was treatment $\mathrm{B}$ with a value of 4.60 means very like.

\subsection{Taste Quality}

Taste is a factor that determines the acceptance or rejection of a food ingredient by panelists. Although the aroma and thickness of the food are good if the taste is not good, the panelist will reject the product. The average value of preference for the taste of Rhodomyrtus tomentosa fruit syrup given by panelists ranged from $3.60-4.50$. The taste the panelists like most is syrup made with treatment B.

Based on the ANOVA test obtained F count (47.48) and then compared with F table which is worth (2.92) at the $5 \%$ real level, it turns out that the calculated $\mathrm{F}$ is greater than $\mathrm{F}$ table so it can be stated that there are significant differences between treatments. The results of the test were continued with Duncan Multiple Range Test (DMRT) at the 5\% level. It is found treatment A had no significant difference with treatment $\mathrm{B}$, and treatment $\mathrm{A}$ had no real difference with the $\mathrm{C}$ and $\mathrm{C}$ treatments have real differences with treatment $\mathrm{B}$. The taste the panelists like is treatment $B$ with a value of 4.50 means very like.

The best syrup product is the act of syrup by heating water and sugar and then adding the cut Rhodomyrtus tomentosa fruit. Syrup B continued with physical and microbiological tests.

\subsection{Physical quality of Rhodomyrtus tomentosa syrup}

Table 1. Quality of physics of Rhodomyrtus tomentosa syrup

\begin{tabular}{lll}
\hline No. & Parameter & quality \\
\hline 1. & pH (\%) & 5,2 \\
2. & invers sugar (\%) & 1,94 \\
3. & Vitamin C (\%) & 0,53 \\
4. & Total acidity (\%) & 0,26 \\
5. & Sugar content (\%) & 17,90 \\
\hline
\end{tabular}

The physical quality test results of syrup drinks contained $0.53 \%$ vitamin C. At the research conducted in Vietnam in 2014 by Thi Ngoc Ha Lai, et al. Vitamin C on Rhodomyrtus tomentosa 
fruit in a weight of 100 grams was $3.746 \mathrm{mg}$. Heating during processing can cause degradation of vitamin $\mathrm{C}$. This is because heat can accelerate the oxidation of vitamin $\mathrm{C}$. Total acid of syrup is $0,26 \%$ and acidity value is 5,2. Syrup sugar levels are quite low at $17.90 \%$. Rhodomyrtus tomentosa fruit syrup products have not met SNI 3544-2013 syrup quality requirements, which are still below $65 \%$.

\subsection{Microbial Test}

The microbiological analysis aims to determine the level of danger of microorganisms contained in beverages. Microbiological analysis is also an indicator of sanitation in the processing or security of food and beverage.

Table 3. Comparison of the results of Karamunting fruit microbe test with SNI

\begin{tabular}{lll}
\hline Microbiological test & Rhodomyrtus tomentosa Syrup & SNI syrup \\
\hline total plate number & $2,5 \times 10^{2}$ & $\leq 5 \times 10^{2} \mathrm{koloni} / \mathrm{ml}$ \\
& & \\
fungi & $1,0 \times 10^{2}$ & Maks $1 \times 10^{2}$ \\
Escherichia coli & negative & $<3$ \\
Staphylococcus aureus & negative & Negative $/ \mathrm{mL}$ \\
Salmonella & negative & Negative $/ 25 \mathrm{~mL}$ \\
\hline
\end{tabular}

Rhodomyrtus tomentosa syrup drink products tested have met microbial requirements based on SNI 3544-2013 Indonesia National Standard (2013) regarding syrup drinks. Based on the tests that have been carried out, the total microbes obtained are still acceptable due to all the Indonesian National Standard for syrup. There are no pathogenic bacteria in the syrup: E.coli, Staphylococcus aureus and Salmonella.

\section{Conclusion}

Rhodomyrtus tomentosa syrup drinks are the most preferred by panelists processed by cutting fruit before cooking. Syrup sugar levels $17.90 \%, \mathrm{pH} 5,2 \%$, total acidity 0,26 and Vitamin C content was $0,53 \%$. Sugar content has not met SNI syrup quality requirements. This syrup product has fulfilled the microbiological quality requirements that have been determined by Indonesian National Standard SNI 3544-2013.

\section{References}

[1] Fahmi, R., Rullah K., Rahmat R.D., Lucida H., Manjang Y., Nordin L., Dachriyanus, (2012), Pengembangan Potensi Rhodomyrtone Sebagai Bahan Aktif Sediaan Topikal, Jurusan Kimia FMIPA Universitas Andalas, Fak. Farmasi Universitas Andalas, cInstitute of Bioscience, University Putra Malaysia.

[2] Sutomo, Arnida, Hernawati F., dan Yuwono, M. (2010). Kajian armakognostik Simpli-sia Daun Karamunting (Rhodomyrtus tomentosa Ait. Hassk) Asal Pelaihari Kalimantan Selatan. FakultasFarmasi Universitas Negeri Airlangga.

[3] Ngoc, T., Lai, C., Andre, H., Rogez, E., Mignolet, T., Nguyen. (2014).Nutritional Composition and antioxidant properties of the sim fruit (Rhodomyrtus tomentosa). Food Chemistry.Available 
from: http://dx.doi.org/10.1016/j.fodchem.2014.07.0810308-8146/Elsevier Ltd.All rights reserved. Accessed February 2015

[4] Samah, Harun, Djamal, Ratnawilis, Abbas, Ginting dan Rasyid. (2008). Penentuan Kadar Fe dan Senyawa Aktif Lainnya Dalam Buah Karamunting (Rhodomyrtus tomentosa W. Ait) Yang Digunakan Sebagai Obat Anemia Pada Wanita Hamil. Project Report. Universitas Andalas. (Unpublished)

[5] Uzlifah, Untsa 2014. Aktivitas Antioksidan Sirup Kombinasi Daun Sirsak (Annona Muricata) Dan Kulit Buah Naga (Hylocereus Costaricensis) Dengan Variasi Lama Perebusan. Artikel Pendidikan Biologi. FKIP. Universitas Muhammadyah Surakarta.

[6] [Syamsuni, H.A. (2007). Ilmu Resep, Kedokteran EGC, Jakarta

[7] BSN (Nasional) (2013). SNI 3544-1994 Tentang Sirup. Jakarta: Badan Standarisasi Badan Standarisasi Nasional. Hal. 1-2.

[8] Suprapti, Lies. 2002. Teknologi Pengolahan Pangan. Penerbit Kanisius.

[9] [Soekarto. 1985. Penilaian Organoleptik Untuk Imdustri Pangan dan Hasil Pertanian. Bhratara Karya Aksara, Jakarta 